\title{
Study on Indoor and Outdoor Fine Particle Exposure Level, Bacterial Composition, and Diversity in a Severe Cold Region of China
}

\author{
Xi Chen, Yang $\mathbf{L v}{ }^{*}$ and Haifeng Wang \\ College of Civil Engineering, Dalian University of Technology, Dalian, 116024, China \\ "For correspondence: 1vyang @ dlut.edu.cn \\ Received 26 September 2020; Accepted 11 November 2020; Published 10 January 2021
}

\begin{abstract}
As there is a frequent occurrence of haze during the heating season in China's severely cold regions, the environmental parameters of the three types of buildings in Daqing were monitored to investigate the concentration and exposure level of particulate matter $2.5\left(\mathrm{PM}_{2.5}\right)$. The short-term exposure levels of $\mathrm{PM}_{2.5}$ for people of different ages and genders were analyzed. The composition and diversity of bacteria were analyzed using 16S rDNA technology. The results showed that the average $\mathrm{PM}_{2.5}$ concentrations of office buildings were higher than that of residential buildings, which was then higher than that of teaching buildings in Daqing. The exposure level of adults in urban areas was $12.0 \%$ higher than those in rural areas. Children had almost the same overall exposure. The potential comprehensive dose and its average dose for adults in urban areas were higher than those in rural areas, and the number of males was higher than females. The risk of exposure increased with age and was higher for males than females. Among the three types of buildings in Daqing, the main bacteria were Proteobacteria, Bacteroidetes and Firmicutes. In the same type of buildings, the total number of bacteria was higher outdoors than indoors and the alpha diversity of bacteria was higher outdoors than indoors. (C) 2021 Friends Science Publishers
\end{abstract}

Keywords: Bacterial component; Bioaerosol; Exposure level; Fine particle; Severe cold region of China

\section{Introduction}

At present, the epidemic caused by the new coronavirus (COVID-19) has become a global public health emergency. Moreover, $98.54 \%$ of the research participants were extremely nervous or afraid of the epidemic (Qi et al. 2020). Therefore, people suggest higher requirements for indoor environment quality. The rapid development of various fields increased pollution to the environment to a greater extent. Air pollution and its health effects have drawn public attention. Studies have shown that the average air pollution index in China declined between 2014 and 2017. Particulate matter $2.5\left(\mathrm{PM}_{2.5}\right)$ was still the main pollutant in urban areas (Zhang and Lin 2019). Several studies have revealed that exposure to higher concentrations of $\mathrm{PM}_{2.5}$ affects the health of residents, which not only endangers the respiratory system but also increases the risk of cardiovascular and cerebrovascular diseases (Chen et al. 2017; Yin et al. 2017a, b). Long-term exposure to high PM concentrations could have significant effects on health. Monn (2001) introduced the concept of exposure assessment in the 1980s. Of these, the exposure and potential dose were commonly used parameters in the evaluation of PM exposure levels. The studies on the assessment of PM exposure have revealed significant results in theory and practice (Gao 2010; Yan et al. 2018). However, most epidemiological studies typically used environmental parameters detected by environmental monitoring stations that did not fit the daily behavior pattern. Studies have shown that Chinese residents spend approximately $80 \%$ of their time indoor (Wang et al. 2014). Outdoor monitoring data alone cannot characterize the actual exposure (He et al. 2004; Ji and Zhao 2015). Therefore, the effects of indoor air quality on human health are more crucial.

$\mathrm{PM}_{2.5}$ and $\mathrm{PM}_{10}$ were easy to become carriers of pollutants, such as microorganisms (Ernest 2004; Cao et al. 2018; Li et al. 2019a). $\mathrm{PM}_{2.5}$ can penetrate into the blood circulation and deep into the respiratory system, thus reaching the lungs. Moreover, $\mathrm{PM}_{2.5}$ has a strong adsorption capacity (Wei et al. 2001). Studies have shown that exposure to $\mathrm{PM}_{2.5}$ has significant adverse effects on ventricular repolarization and may cause vascular insulin resistance (Haberzettl et al. 2016; Wang et al. 2020). In previous studies, more attention was given to the physical and chemical properties (Li et al. 2019b; Liu et al. 2019b). The biological component is called bioaerosol defined as the collection of particles released into the atmosphere by the biosphere (Frhlich-nowoisky et al. 2016). The proportion of bioaerosols in the air was typically about $30 \%$, and the proportion was higher in areas covered by vegetation (Graham et al. 2003; Després et al. 2012; Huffman et al. 2012, 2013). High levels of bacteria are found in vehicle air 
conditioning systems (Li et al. 2013). Studies have shown that the reduction in bioaerosols increases after being transported by air and could induce respiratory diseases (Estillore et al. 2016; Wang et al. 2018). Moreover, its negative effects increase in haze weather (Wang et al. 2015). Bioaerosols also increase the risk of spreading resistance genes (Li et al. 2018; Chen et al. 2020). In the HVAC system, Yu et al. (2019) found that yeast and Penicillium are the main species on the basement walls of residential buildings. Liu et al. (2019a) found that live bacteria were the highest in the fresh air.

Because of the special geographical location, climatic conditions, and building types in China's severe cold regions, the pollution of $\mathrm{PM}_{2.5}$ was more serious. To explore $\mathrm{PM}_{2.5}$ and bacteria in the building environment in China's severe cold regions, this study selected Daqing, Heilongjiang province. To further analyze the health effects of $\mathrm{PM}_{2.5}$ onpeople of different ages and genders, the study monitored indoor and outdoor environmental parameters in offices, schools, and residential buildings. The two indicators of exposure and potential dose were used in the risk assessment of health exposure.16Sr DNA technology was used to analyze the composition and diversity of bacteria in indoor $\mathrm{PM}_{2.5}$. This study aimed to investigate the effects of bioaerosols on the indoor environment and the health of humans.

\section{Materials and Methods}

This study selected Daqing in the severe cold region of China as the study location. Daqing (N45 $46^{\prime} \sim 46^{\circ} 55^{\prime}$, E124 $19^{\prime} \sim 125^{\circ} 12^{\prime}$ ) is in Heilongjiang province, China. In winter, a large number of fine particles are emitted because of heating. In addition, Daqing has a leading number of petrochemical industries; thus, there is serious industrial pollution. The above problems had exacerbated the pollution of fine particles in the heating season in Daqing.

Considering the frequency of use, daily activities of the population and length of stay, this study selected three types of buildings for research: office buildings, teaching buildings, and residential buildings. In this study, 110 sampling points were selected in Daqing, including 30 office buildings, 30 teaching buildings, and 50 residences, to ensure statistically significant sample sizes. Among them, office buildings and teaching buildings were in the urban areas, and 38 residential buildings were urban houses, and 12 were rural houses. The sampling objects of the office building were the conference room. The indoor objects of the teaching buildings were the classroom, and the outdoor objects were the corridor. The measurement objects of residential buildings were living rooms with a balcony. The measurement was taken in the heating season from November 2016 to March 2017. During the actual measurement period, there were radiators indoors, and the envelopes such as doors and windows were generally closed. The arrangement of the measuring points during the actual measurement is based on the Indoor Air Quality Standards (GBT18883-2002 2002). The measuring points were categorized into the indoor and outdoor points of the building. The outdoor points were arranged in the center of the open external balcony, which was more than $0.5 \mathrm{~m}$ away from the wall structure and higher than the height of the external balcony railing. The indoor points were arranged uniformly in the living room of the residence, $0.5 \mathrm{~m}$ above the wall and $0.5 \mathrm{~m}$ above the ground.

The indoor and outdoor environments of each sampling point were simultaneously monitored. The QT-50 particle online monitor was used to continuously measure environmental parameters such as temperature, relative humidity, and $\mathrm{PM}_{2.5}$ mass concentration. The detection interval of the monitor was set to $15 \mathrm{~min}$ and data were collected for seven days at each monitoring point. The QT50 particle online monitor was compared with multiple machines before using. QT-50 and TSI8530 were placed in the same environment for simultaneous detection. The measurement results of the QT-50 particle detector were corrected on the basis of the detection results. The biological components of $\mathrm{PM}_{2.5}$ were collected using the membrane sampling method. Omni 5000IS mobile air sampling pumps equipped with a $\mathrm{PM}_{2.5}$ cutting head was used for sampling. The flow rate of a single sample was set to $4000 \mathrm{~mL} \mathrm{~min}^{-1}$, and the time was set to $24 \mathrm{~h}$. The filter membrane consists of Teflon filters with a diameter of $37 \mathrm{~mm}$ and a pore diameter of 2.0 microns (Whattman, Maidstone, Kent, UK). It was checked for pinholes and wrinkles under the light before using to avoid affecting the filtration efficiency. The filter membranes before and after use were weighed using an electronic balance. The filters after sampling were stored in the refrigerator.

The permeability coefficient $\left(\mathrm{F}_{\text {inf }}\right)$ characterizes the proportion of outdoor PM that enters the room and is suspended in the air at equilibrium. The generalized permeability coefficient includes the contribution of all indoor and outdoor ambient air exchange forms to the concentration of indoor PM, while considering the effects of indoor particulate emission sources $\left(\mathrm{C}_{\mathrm{s}}\right)$, which can be expressed using the following formula:

$$
C_{\text {in }}=F_{\text {inf }} C_{\text {out }}+C_{s}
$$

Where $\mathrm{C}_{\mathrm{in}}$ is indoor particle concentration $\left(\mu \mathrm{g} \mathrm{hm}^{-3}\right) ; \mathrm{C}_{\text {out }}$ is outdoor $\mathrm{PM}$ concentration $\left(\mu \mathrm{g} \mathrm{hm}^{-3}\right) ; \mathrm{C}_{\mathrm{s}}$ is indoor particulate emission source $\left(\mu \mathrm{g} \mathrm{hm}{ }^{-3}\right)$; and $F_{\text {inf }}$ is permeability coefficient.

For evaluation of PM exposure, this study used four indicators: comprehensive exposure, average comprehensive exposure, comprehensive potential dose and average comprehensive potential dose. The amount of exposure reflected the total amount of particulates that the human body had been exposed to in different periods. The dose reflected the total exposure time with respiration inhaled particles (Monn 2001; Yip et al. 2004; Edgar 2013). 
The formulas were as follows:

$$
\begin{aligned}
& E_{z}=\sum_{i=1}^{n} C_{i} T_{i} \\
& \bar{E}_{z}=\frac{E_{z}}{T}=\frac{\sum_{i=1}^{n} C_{i} T_{i}}{\sum_{i=1}^{n} T_{i}} \\
& D_{z}=\sum_{i=1}^{n} C_{i} \cdot I R_{i} \cdot T_{i} \\
& \bar{D}_{z}=\frac{D_{z}}{T}=\frac{\sum_{i=1}^{n} C_{i} \cdot I R_{i} \cdot T_{i}}{\sum_{i=1}^{n} T_{i}}
\end{aligned}
$$

Where $E_{z}$ is comprehensive exposure $\left(\mu \mathrm{g} \mathrm{hm}^{-3}\right) ; \bar{E}_{z}$ is average comprehensive exposure $\left(\mu \mathrm{g} \mathrm{hm}^{-3}\right) ; \mathrm{C}_{\mathrm{i}}$ is exposure concentration $\left(\mu \mathrm{gm}^{-3}\right) ; \mathrm{T}_{\mathrm{i}}$ is the exposure time (h); Tis the total exposure time $(\mathrm{h}) ; \mathrm{D}_{\mathrm{z}}$ is a comprehensive potential dose $(\mu \mathrm{g}) ; \overline{\mathrm{D}}_{z}$ is average comprehensive potential dose $(\mu \mathrm{g})$; and $I_{\mathrm{i}}$ is respiratory rate $\left(\mathrm{m}^{3} \mathrm{~h}^{-1}\right)$.

The microbial genes on the filter were extracted using $16 \mathrm{~S}$ rDNA technology. DNA was extracted using the cetyltrimethylammonium bromide method, and the purity and concentration of the DNA were detected using agarose gel electrophoresis. The library was constructed using the Ion Plus Fragment Library Kit 48 rxns Library Thermo Kit (Thermo Fisher, Waltham, Massachusetts, U.S.) and tested. After the library was qualified, it was sequenced using Life Ion S5TM or Ion S5TMXL (Thermofisher). Using Cutadapt (v. 1.9.1), the low-quality portion, and barcode primer sequences, the original data were obtained (Wang et al. 2007; Dons et al. 2011). UCHIME algorithm was used to cross-compare with GOLD database to remove the chimeric sequence for obtaining valid data. The effective data were clustered using UPARSE software (Quast et al. 2013), and species annotation was performed using the Mothur method and SILVA's SSUrRNA database (Wei and Zhang 2018).

\section{Results}

Results of indoor and outdoor fine particulate matter concentration distribution during heating season

Fig. 1-3 showed the average distribution of indoor and outdoor fine particle concentrations of three types of buildings in Daqing during the heating season. The national standard "Ambient Air Quality Standard" (GB3059-2012 2012) stipulated that the outdoor average daily $\mathrm{PM}_{2.5}$ concentration in China should be less than $75 \mu \mathrm{g} \mathrm{m}^{-3}$. The industry standard "Building Ventilation Effect Test and Evaluation Standard" (JGJ/T309-2013 2013) limited the average daily $\mathrm{PM}_{2.5}$ concentration to $75 \mu \mathrm{g} \mathrm{m}^{-3}$ as a reference.

Fig. 1 showed that during the heating season, the average $\mathrm{PM}_{2.5}$ mass concentrations of indoor and outdoor office buildings in Daqing were $43.7 \mu \mathrm{g} \mathrm{m}^{-3}$ and $75.5 \mu \mathrm{g}$ $\mathrm{m}^{-3}$, respectively. The average $\mathrm{PM}_{2.5}$ permeability coefficient of indoor and outdoor office buildings was 0.341. Fig. 2 showed that the average $\mathrm{PM}_{2.5}$ mass concentrations of the indoor and outdoor teaching buildings in Daqing during

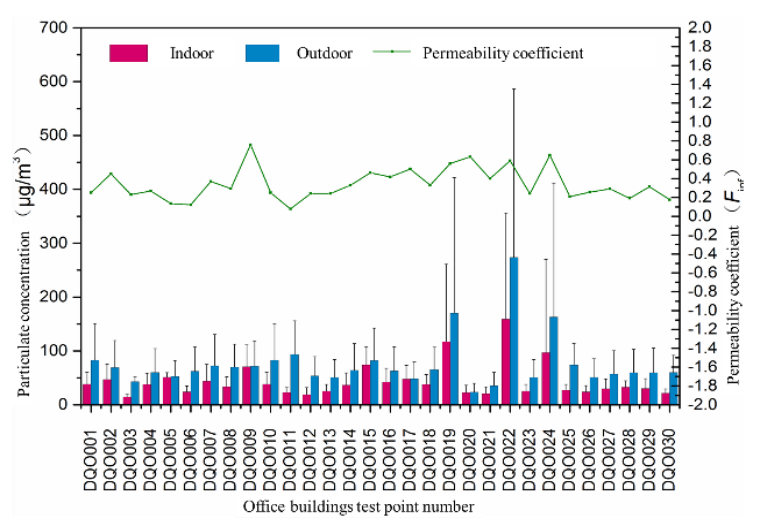

(a) Office building

Fig. 1: The average $\mathrm{PM}_{2.5}$ concentration of indoor and outdoor measuring points of office buildings in the heating season of Daqing

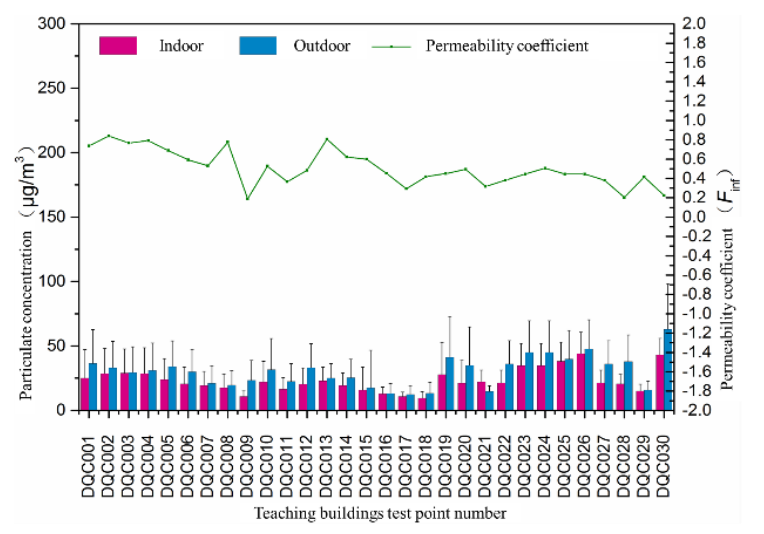

Fig. 2: The average $\mathrm{PM}_{2.5}$ concentration of indoor and outdoor measuring points of teaching buildings in the heating season of Daqing

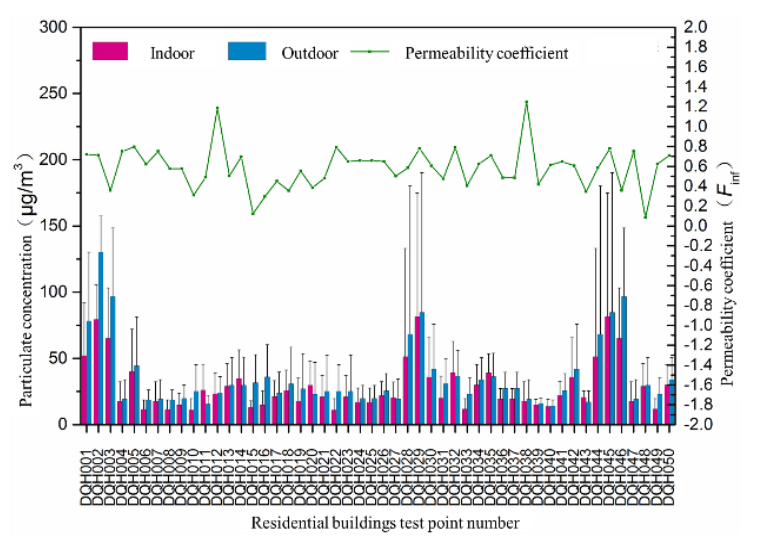

Fig. 3: The average $\mathrm{PM}_{2.5}$ concentration of indoor and outdoor measuring points of residential buildings in the heating season of Daqing

the heating season were $23.0 \mu \mathrm{g} \mathrm{m}^{-3}$ and $30.0 \mu \mathrm{g} \mathrm{m}^{-3}$, respectively. The average $\mathrm{PM}_{2.5}$ permeability coefficient inside and outside the teaching buildings was 0.5175 . 
Fig. 3 showed that the average $\mathrm{PM}_{2.5}$ mass concentrations of indoor and outdoor residential buildings in Daqing during the heating season were $28.9 \mu \mathrm{g} \mathrm{m}^{-3}$ and $36.0 \mu \mathrm{g} \mathrm{m}^{-3}$, respectively. The average indoor and outdoor $\mathrm{PM}_{2.5}$ mass concentrations of the urban and rural residential building were $27.7 \mu \mathrm{g} \mathrm{m}^{-3}$ and $35 \mu \mathrm{g} \mathrm{m}^{-3}$ and $21.2 \mu \mathrm{g} \mathrm{m}^{-3}$ and $27.2 \mu \mathrm{g}$ $\mathrm{m}^{-3}$, respectively. The average $\mathrm{PM}_{2.5}$ permeability coefficient of urban residents was 0.6016 and that of rural residents was 0.5434 .

In summary, the average mass concentration of the indoor and outdoor $\mathrm{PM}_{2.5}$ of the three types of buildings in Daqing during the heating season mostly met the national standards. In addition, because of the low winter temperatures in the severe cold regions, fossil fuels were required for heating, and several fine particles were discharged into the air. Because of adverse meteorological factors, outdoor $\mathrm{PM}_{2.5}$ concentrations can rise rapidly in a short time. Moreover, as the enclosure structures such as indoor and outdoor doors and windows were in a closed state during the heating season, this hinders the transmission process of outdoor $\mathrm{PM}$ to the interior, thus increasing the difference between indoor and outdoor PM concentrations.

\section{Study on exposure assessment methods}

Parameters such as $\mathrm{Ci}$ and $\mathrm{Ti}$ in the exposure evaluation index formula can be obtained from the monitored environmental data. However, there were still some parameters that need to be referenced in related specifications. This study investigated three types of buildings: office buildings, teaching buildings, and residential buildings, including people of different ages and genders. The actual measurement showed that office buildings mainly involved adult groups, whereas the groups in the teaching buildings were mainly school-aged children. Because of the different urban and rural environments, the adult population spent a different amount of time in different types of buildings, leading to urban-rural differences. In this study, the adult population was mainly divided into urban and rural populations. The daily activities of urban residents were mainly concentrated in office buildings and residences. The rural residents have the agricultural leisure period in the heating season, and most activities were concentrated in residence. In addition, gender factors were considered. The teaching building in this study was a primary school, and the group in the teaching building was mainly children aged from 6 to 12 years. Refer to the "Chinese Population Exposure Parameter Manual" (Ministry of Environmental Protection 2013a, b) to select the indoor and outdoor activities of urban and rural populations during the heating season, as shown in Table 14. In addition, the urban population spent13.5 $\mathrm{h}$ in indoor activities, $1.5 \mathrm{~h}$ in outdoor activities, and $9 \mathrm{~h}$ in office. The indoor activity time of the rural population was $22.5 \mathrm{~h}$, and the outdoor activity time was $1.5 \mathrm{~h}$.
The actual measurement of this study was performed in Daqing in the severe cold region. The measured data were collected for seven days at each measurement point. The measured data were then combined with information such as the activity status of different groups and used in the formula. The exposure of the adult population in different regions is shown in Table 5. Moreover, adult males and females were shown to have the same time activity pattern. Therefore, the analysis did not distinguish between gender factors in urban and rural populations.

The comprehensive exposure of the urban population in the heating season of Daqing was $6370 \mu \mathrm{g} \cdot \mathrm{hm}^{-3}$, and the average comprehensive exposure was $37.92 \mu \mathrm{g} \mathrm{m}^{-3}$. For the rural population, the comprehensive exposure was 5607 $\mu \mathrm{g} \mathrm{hm}^{-3}$, and the average comprehensive exposure was $33.38 \mu \mathrm{g} \mathrm{m}^{-3}$. In general, the exposure of the urban population was higher than that of the rural population, with a difference of $12.0 \%$.

In addition, the risk of exposure to fine PM in children of different ages and genders was analyzed. The exposure of children to fine particles in three types of buildings during the heating season is shown in Table 6. The combined exposure of males aged 6 to 9 years was $4626.1 \mu \mathrm{g} \mathrm{hm}^{-3}$ and that of females was $4642.5 \mu \mathrm{g} \mathrm{hm}^{-3}$. Average comprehensive exposure was approximately $27.5 \mu \mathrm{g} \mathrm{m}^{-3}$. Among children aged 9 to 12 years, the combined exposure of males and females was $4625.9 \mu \mathrm{g} \mathrm{hm}$ and $4625.3 \mu \mathrm{g} \mathrm{hm}^{-3}$, respectively. The average comprehensive exposure was approximately $27.5 \mu \mathrm{g} \mathrm{m}^{-3}$. The comprehensive exposure of children of different ages and genders was slightly different because of different time-activity patterns, and the average comprehensive exposure was approximately equal.

The comprehensive exposure and average comprehensive exposure indicators can only characterize the level of fine particulates in the external environment. They do not consider factors such as gender, the content of activities and resulting differences in the breathing rate. Therefore, the combined potential dose and its average dose were used as two indexes to characterize the dose of fine particles inhaled into the human body as a breathing effect.

Table 7 and 8 show the calculation of the potential doses at different breathing rates for adult males and females in different states. Table 7 displays that the potential dose of urban males during the heating season in Daqing was $2769.62 \mu \mathrm{g}$, and its average dose was $16.49 \mu \mathrm{g} \mathrm{h}^{-1}$. The comprehensive potential dose of rural males was 2162.44 $\mu \mathrm{g}$, and the average dose was $12.87 \mu \mathrm{g} \mathrm{h}^{-1}$. The overall potential dose of urban males was approximately $21.9 \%$ higher than that of rural males. Table 8 shows that the comprehensive potential dose of urban females during the heating season of Daqing was $2273.04 \mu \mathrm{g}$, and its average dose was $13.53 \mu \mathrm{g} \mathrm{h}^{-1}$. The comprehensive potential dose of rural females was $1777.55 \mu \mathrm{g}$, and its average dose was $10.58 \mu \mathrm{g} \mathrm{h}^{-1}$.

Table 9 shows the calculation of the potential dose considering children's activity status and respiratory rate in 
Bacterial Diversity in Severe Cold Region of China / Intl J Agric Biol, Vol 25, No 2, 2021

Table 1: The activity time of children of different genders in heating season (Ministry of Environmental Protection 2013b).

\begin{tabular}{llccc}
\hline Age & Gender & Indoor time $(\mathrm{h})$ & School time $(\mathrm{h})$ & Outdoor time $(\mathrm{h})$ \\
\hline $6-<$ 9years old & Male & 15.57 & 6.00 & 2.43 \\
& Female & 15.65 & 6.00 & 2.35 \\
$-<12$ years old & Male & $15.60 \mathrm{~h}$ & 6.00 & 2.40 \\
& Female & $15.68 \mathrm{~h}$ & 6.00 & 2.32 \\
\hline
\end{tabular}

Note: The students in the measured area are in school for $6 \mathrm{~h}$

Table 2: Classification and description of different labor intensity (Ministry of Environmental Protection 2013a)

\begin{tabular}{ll}
\hline Labor intensity classification & Description \\
\hline Rest & sleep, recline, and rest \\
Extremely light activity & sitting or standing, typing, sewing, ironing, cooking, etc. \\
Mild activity & walking on a flat road at a speed of $4-4.8 \mathrm{~km} \cdot \mathrm{h}^{-1}$, clean room hygiene, childcare, sports, etc. \\
Moderate activity & walking at a speed of $5.6-6.4 \mathrm{~km} \cdot \mathrm{h}^{-1}$, weeding or mowing, carrying heavy objects, riding aerobic, etc. \\
Heavy activity & load uphill walking, felling trees, vigorous exercise, etc.
\end{tabular}

Heavy activity

Table 3: Respiratory rate of adults under different activities (Ministry of Environmental Protection 2013a)

\begin{tabular}{llcccc}
\hline Gender & \multicolumn{4}{c}{ Respiratory rate $\left(\mathrm{m}^{3} \cdot \mathrm{h}^{-1}\right)$} \\
\cline { 2 - 5 } & Rest & Extremely light activity & Mild activity & Moderate activity & Heavy activity \\
\hline Male & 0.372 & 0.444 & 0.558 & 1.488 & 2.232 \\
Female & 0.306 & 0.366 & 0.456 & 1.212 & 1.818 \\
\hline
\end{tabular}

Table 4: Respiratory rate of children under different activities (Ministry of Environmental Protection 2013b).

\begin{tabular}{lllcccc}
\hline Age & Gender & \multicolumn{5}{c}{ Respiratory rate $\left(\mathrm{m}^{3} \cdot \mathrm{h}^{-1}\right)$} \\
\cline { 3 - 6 } & & Rest & Extremely light activity & Mild activity & Moderate activity & Heavy activity \\
\hline 6 to 9 years old & Male & 0.258 & 0.312 & 0.516 & 1.038 & 2.586 \\
& Female & 0.234 & 0.282 & 0.468 & 0.930 & 2.328 \\
9 to 12 years old & Male & 0.306 & 0.366 & 0.612 & 1.224 & 3.060 \\
& Female & 0.270 & 0.324 & 0.540 & 1.080 & 2.706 \\
\hline
\end{tabular}

Table 5: Exposure of fine particulates in different adult populations

\begin{tabular}{lllcc}
\hline Types of population & Location & Exposure $\left(\mu \mathrm{g} \cdot \mathrm{h} \cdot \mathrm{m}^{-3}\right)$ & Comprehensive exposure $\left(\mu \mathrm{g} \cdot \mathrm{h} \cdot \mathrm{m}^{-3}\right)$ & Average comprehensive exposure $\left(\mu \mathrm{g} \cdot \mathrm{m}^{-3}\right)$ \\
\hline Urban populations & Office building & 2772 & 6370 & 37.92 \\
& Residential & 2548 & & \\
& Outdoor & 1050 & 5607 & 33.38 \\
Rural populations & Residential & 5198 & & \\
& Outdoor & 410 & & \\
\hline
\end{tabular}

Table 6: Exposure of fine particulates in children of different ages

\begin{tabular}{|c|c|c|c|c|c|}
\hline \multicolumn{2}{|c|}{ Types of population } & Location & Exposure $\left(\mu \mathrm{g} \cdot \mathrm{h} \cdot \mathrm{m}^{-3}\right)$ & Comprehensive exposure $\left(\mu \mathrm{g} \cdot \mathrm{h} \cdot \mathrm{m}^{-3}\right)$ & Average comprehensive exposure $\left(\mu \mathrm{g} \cdot \mathrm{m}^{-3}\right)$ \\
\hline \multirow[t]{6}{*}{6 to 9 years old } & Male & Residential & 3149.8 & 4626.1 & 27.5 \\
\hline & & School & 966.0 & & \\
\hline & & Outdoor & 510.3 & & \\
\hline & Female & Residential & 3166.0 & 4642.5 & 27.5 \\
\hline & & School & 966.0 & & \\
\hline & & Outdoor & 493.5 & & \\
\hline \multirow[t]{6}{*}{9 to 12 years old } & Male & Residential & 3155.9 & 4625.9 & 27.5 \\
\hline & & School & 966.0 & & \\
\hline & & Outdoor & 504.0 & & \\
\hline & Female & Residential & 3172.1 & 4625.3 & 27.5 \\
\hline & & School & 966.0 & & \\
\hline & & Outdoor & 487.2 & & \\
\hline
\end{tabular}

different environments. In male and female children aged 6 to 9 years, the comprehensive potential dose was $1377.36 \mu \mathrm{g}$ and $1244.21 \mu \mathrm{g}$, respectively. The average total potential dose for males and females was $8.20 \mu \mathrm{g} \mathrm{h}^{-1}$ and $7.41 \mu \mathrm{g} \mathrm{h}^{-1}$, respectively. In children aged 6 to 9 years, the combined potential dose and its average dose of males were $9.6 \%$ higher than that of females. The combined potential dose for children aged between 9 and 12 years was $1627.70 \mu \mathrm{g}$ for males and $1432.53 \mu \mathrm{g}$ for females, and the average comprehensive potential dose was 9.69 and $8.53 \mu \mathrm{g} \mathrm{h}^{-1}$, respectively.

The results of bacterial components of fine particles inside and outside the three types of buildings in Daqing during the heating period. Moreover, the figures show the top 10 predominant bacteria at the phylum level. The coordinates of city and farm referring to urban and rural residential buildings, respectively (Fig. 4 and 5). 
Table 7: Potential exposure dose of fine particles for males

\begin{tabular}{llllll}
\hline $\begin{array}{l}\text { Types of } \\
\text { population }\end{array}$ & Location & Exposure $\left.(\mu \mathrm{g} \mathrm{h} \mathrm{m})^{-3}\right)$ & $\begin{array}{l}\text { Respiratory rate } \\
\left(\mathrm{m}^{3} \mathrm{~h}^{-1}\right)\end{array}$ & $\begin{array}{l}\text { Comprehensive potential dose } \\
(\mu \mathrm{g})\end{array}$ & $\begin{array}{l}\text { Average comprehensive potential dose } \\
\left(\mu \mathrm{g} \cdot \mathrm{h}^{-1}\right)\end{array}$ \\
\hline Urban populations & Office building & 2772 & 0.444 & 2769.62 & 16.49 \\
& Residential & 2548 & 0.372 & & \\
& Outdoor & 1050 & 0.558 & 2162.44 & 12.87 \\
Rural populations & Residential & 5198 & 0.372 & & \\
& Outdoor & 410 & 0.558 & & \\
\end{tabular}

Table 8: Female potential exposure dose of fine particles

\begin{tabular}{|c|c|c|c|c|c|}
\hline $\begin{array}{l}\text { Types of } \\
\text { population }\end{array}$ & Location & Exposure $\left(\mu \mathrm{g} \mathrm{h} \mathrm{m}^{-3}\right)$ & $\begin{array}{l}\text { Respiratory rate } \\
\left(\mathrm{m}^{3} \mathrm{~h}^{-1}\right)\end{array}$ & $\begin{array}{l}\text { Comprehensive potential dose } \\
(\mu \mathrm{g})\end{array}$ & $\begin{array}{l}\text { Average comprehensive potential dose } \\
\left(\mu \mathrm{g} \cdot \mathrm{h}^{-1}\right)\end{array}$ \\
\hline \multirow[t]{2}{*}{ Urban populations } & Office building & 2772 & 0.366 & \multirow[t]{2}{*}{2273.04} & \multirow[t]{2}{*}{13.53} \\
\hline & Residential & 2548 & 0.306 & & \\
\hline \multirow[t]{2}{*}{ Rural populations } & Residential & 5198 & 0.306 & \multirow[t]{2}{*}{1777.55} & \multirow[t]{2}{*}{10.58} \\
\hline & Outdoor & 410 & 0.456 & & \\
\hline
\end{tabular}

Table 9: Potential exposure dose of fine particles in children

\begin{tabular}{|c|c|c|c|c|c|c|}
\hline \multicolumn{2}{|c|}{ Types of population } & \multirow{2}{*}{$\begin{array}{l}\text { Location } \\
\text { Residential }\end{array}$} & \multirow{2}{*}{$\begin{array}{l}\text { Exposure }(\mu \mathrm{gh} \\
\left.\mathrm{m}^{-3}\right)\end{array}$} & \multirow{2}{*}{$\begin{array}{l}\text { Respiratory rate } \\
\left(\mathrm{m}^{3} \mathrm{~h}^{-1}\right)\end{array}$} & \multirow{2}{*}{$\begin{array}{l}\text { Comprehensive potential dose } \\
(\mu \mathrm{g}) \\
1377.36\end{array}$} & \multirow{2}{*}{$\begin{array}{l}\begin{array}{l}\text { Average comprehensive potential } \\
\text { dose }\left(\mu \mathrm{g} \mathrm{h}^{-1}\right)\end{array} \\
8.20\end{array}$} \\
\hline 6 to 9 years old & Male & & & & & \\
\hline & & School & 966.0 & 0.312 & & \\
\hline & & Outdoor & 510.3 & 0.516 & & \\
\hline & Female & Residential & 3166.0 & 0.234 & 1244.21 & 7.41 \\
\hline & & School & 966.0 & 0.282 & & \\
\hline & & Outdoor & 493.5 & 0.468 & & \\
\hline \multirow[t]{6}{*}{9 to 12 years old } & Male & Residential & 3155.9 & 0.306 & 1627.70 & 9.69 \\
\hline & & School & 966.0 & 0.366 & & \\
\hline & & Outdoor & 504.0 & 0.612 & & \\
\hline & Female & Residential & 3172.1 & 0.270 & 1432.53 & 8.53 \\
\hline & & School & 966.0 & 0.324 & & \\
\hline & & Outdoor & 487.2 & 0.540 & & \\
\hline
\end{tabular}

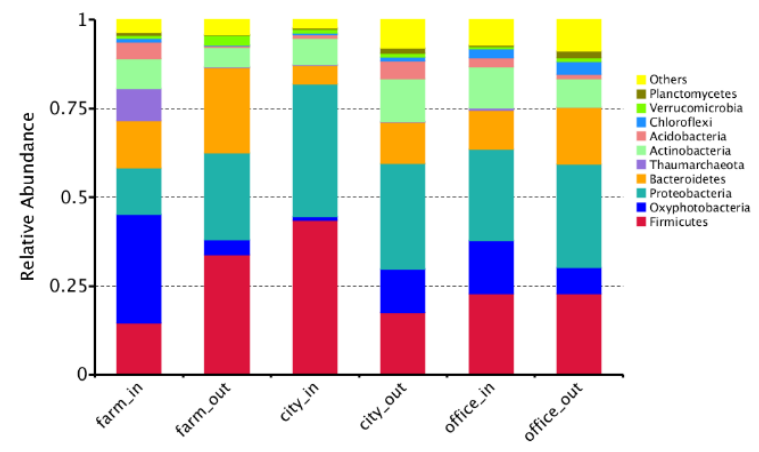

Fig. 4: Histograms of indoor and outdoor top 10 bacterial components of office and residential buildings in Daqing heating season

The dominant bacteria of indoor and outdoor fine particles in office buildings and urban and rural residential buildings were Firmicutes, Oxyphotobacteria, Proteobacteria, Bacteroidetes, Thaumarchaeota, Actinobacteria, Acidobacteria, Chloroflexi, Verrucomicrobia, and Planctomycetes. Among these, the main dominant species of rural residential buildings were Firmicutes, Oxyphotobacteria and Proteobacteria. Fig. 5 shows that the top 10 dominant bacteria of the

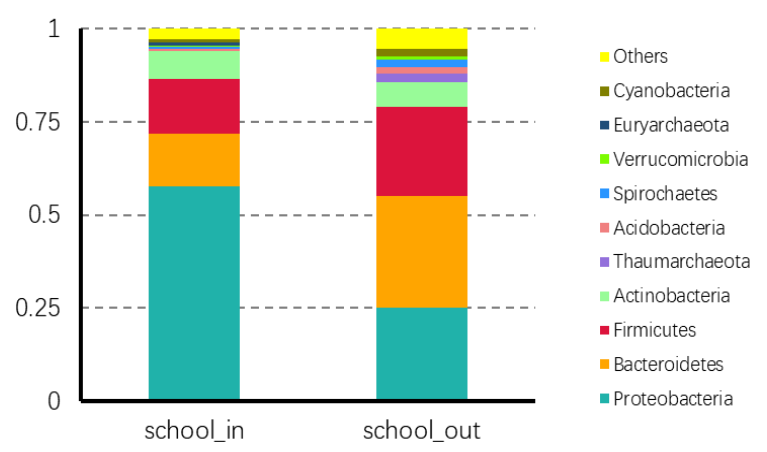

Fig. 5: Histograms of indoor and outdoor top 10 bacterial components of teaching buildings in Daqing heating season

indoor and outdoor fine particles of Daqing teaching buildings during the heating season were Proteobacteria, Bacteroidetes, Firmicutes, Actinobacteria, Thaumarchaeota, Acidobacteria, Spirochaetes, Verrucomicrobia, Euryarchaeota and Cyanobacteria (Fig. 4). In summary, Proteobacteria, Bacteroidetes, and Firmicutes were the main dominant bacteria of fine PM in the indoor and outdoor of three types of buildings in Daqing during the heating season. 
Bacterial Diversity in Severe Cold Region of China / Intl J Agric Biol, Vol 25, No 2, 2021

Table 10: Alpha diversity index statistics

\begin{tabular}{llccccc}
\hline Group & Goods coverage & Observed species & chaol index & ACE index & Shannon index & Simpson index \\
\hline Urban house indoor & 0.996 & 534 & 678.523 & 706.252 & 5.884 & 0.928 \\
Urban house outdoor & 0.996 & 587 & 738.447 & 810.45 & 7.045 & 0.973 \\
Rural house indoor & 0.995 & 814 & 958.741 & 967.2 & 6.245 & 0.907 \\
Rural house outdoor & 0.991 & 1310 & 1575.849 & 1640.253 & 6.942 & 0.964 \\
Office building indoor & 0.995 & 515 & 845.676 & 904.654 & 6.929 & 0.981 \\
Office building outdoor & 0.987 & 2251 & 2566.894 & 2634.976 & 8.642 & 0.99 \\
\hline
\end{tabular}

In the three types of buildings in Daqing during the heating season, the indoor and outdoor flora of residential and office buildings were similar, and the top 10 dominant bacteria at the phylum level were the same. To further compare the similarities and differences between residential buildings and office buildings, the bacterial diversity of indoor and outdoor fine particles was analyzed. Table 8 shows the statistical results of the alpha diversity index of bacteria of indoor and outdoor fine particles of residential buildings (including rural and urban residence) and office buildings.

Table 10 shows that the goods coverage values in the samples collected in the actual measurement exceeded $98 \%$, indicating that most genes could be detected using the library, and the detection results were more in line with actual conditions.

The ACE index and the chaol index estimate the number of OTUs (Operational Taxonomic Units) in their microbial communities using different algorithms. The larger the Simpson index value, the lower the diversity of colonies. The higher the value, the higher the richness. Shannon and Simpson' indexes reflect the uniformity of the flora. The higher the Shannon value, the higher the uniformity. For urban residential buildings, the number of observed species outdoors was similar to that indoors. The abundance and uniformity of outdoor bacteria were slightly higher than that of indoors. However, the number of observed species outdoors in rural residential buildings was significantly higher than indoors. In addition, the richness of outdoor bacteria was significantly higher than that of indoor bacteria.

\section{Discussion}

The outdoor $\mathrm{PM}_{2.5}$ concentration of office buildings was higher than indoor. The high concentration of outdoor $\mathrm{PM}_{2.5}$ may contribute to the concentration of indoor $\mathrm{PM}_{2.5}$. The outdoor $\mathrm{PM}_{2.5}$ concentration at most measuring points in office buildings met the national standards. Except for individual measurement points, the indoor $\mathrm{PM}_{2.5}$ concentration of office buildings met industry standards. The indoor and outdoor $\mathrm{PM}_{2.5}$ mass concentrations at the measuring points of the teaching building were less than the limit. This may be because teaching buildings were generally far from industrial areas, and the surrounding air quality was better. In addition, there was not much difference between the indoor and outdoor $\mathrm{PM}_{2.5}$ concentrations, which may be because of the large number of personnel in the teaching building and the frequent air circulation. In general, except for individual measurement points, the indoor and outdoor $\mathrm{PM}_{2.5}$ mass concentrations of residential buildings were less than the limit. The indoor and outdoor air quality of rural residential buildings was generally better than that of urban residential buildings, which may be associated with traffic pollution caused by dense traffic in cities.

From the perspective of comprehensive exposure indicators, the overall exposure of the adult population was higher than that of the children. This may be because of the different living environments of different age groups. Compared with adults, children spent most of their time in schools and indoors, and the fine particle concentration was low in the exposure environment. On comparing people of different genders in the same age group, the average combined exposure of males and females was not significantly different.

The comprehensive potential dose and its average dose of urban females were $21.8 \%$ higher than that of rural females. Overall, the combined potential dose and its average dose of the urban population were higher than that of the rural population. However, regardless of the urban or rural population, the average potential dose of males was $22.0 \%$ higher than that of females because of the difference in the breathing rate between different genders. Among children aged 9 to 12 years, the combined potential dose and its average dose of males were $12 \%$ higher than that of females. On comparing children of the same gender and different ages, the comprehensive potential dose and its average dose of males aged between 9 and 12 years were $15.4 \%$ higher than those aged between 6 and 9 years. The combined potential dose and its average dose of female children aged between 9 and 12 years were $13.1 \%$ higher than those aged between 6 and 9 years. In general, the health risk of fine particles in male children was higher than that in female children.

In summary, the risk of fine particle exposure was higher in urban areas than in rural areas and in males than females of the same area. Among children, males of the same age group were at a higher risk of exposure to fine particles than females. Moreover, the risk of exposure increased with age. Some studies have revealed that longterm and short-term exposure to $\mathrm{PM}_{2.5}$ was statistically positively correlated with anxiety (Braithwaite et al. 2019). The potential relationship between air pollution and poor mental health needs further research. 
In office and residential buildings, a comparison of indoor and outdoor bacterial components showed that the indoor Oxyphotobacteria was higher than outdoor. Oxyphotobacteria is mainly distributed in anoxic areas where light can transmit in an aquatic environment. The high proportion of Oxyphotobacteria in rural residential indoors may be because of its low indoor temperature, which was not conducive to water evaporation and leads to more indoor water retention. In addition, the proportion of Thaumarchaeota was higher in indoor air than in other samples. Thaumarchaeota is mainly distributed in areas without light. Poor lighting conditions in rural homes may result in a higher proportion of Thaumarchaeota. The dominant species of indoor and outdoor urban residential buildings were Firmicutes, Proteobacteria, and Bacteroidetes. A higher proportion of Firmicutes and Proteobacteria was noted outdoor than indoor, which may be because of the weak indoor ultraviolet lights. The dominant strains of indoor and outdoor bacteria in office buildings were Firmicutes, Proteobacteria, and Bacteroidetes. Moreover, the proportion of bacteria in different categories was similar indoors and outdoors.

The composition of the dominant species changed in the other two types of buildings. Proteobacteria accounted for more than 50\% in the classroom. Proteobacteria is the largest group of bacteria, including several pathogenic bacteria. The high proportion of Proteobacteria in the classroom building may be because of the pathogenic bacteria carried by densely packed personnel. In addition, a small amount of Thaumarchaeota was found outside the school buildings, which may be associated with outdoor playgrounds and green plants. In addition, Proteobacteria is a spoilage bacterium, and food is very susceptible to infection. In addition, no obvious change was observed in the characteristics of contaminated food, which can easily cause food poisoning. Proteobacteria can also cause chronic otitis media, traumatic infections, cystitis, infantile diarrhea, etc. (Liu and Zhang 2012).

On comparing residential buildings in urban and rural areas, the observed species were higher in rural than urban areas. In addition, the abundance and uniformity of bacteria in rural areas were higher than that in cities. The indoor and outdoor $\mathrm{PM}_{2.5}$ concentration in rural residential buildings was higher than that in urban areas, which may provide a carrier for the spread. Therefore, the bacterial diversity in rural areas was higher than that in cities. The observed species indoors for urban office buildings were similar to that of urban residential buildings. The observed species outside the office buildings was about four times that inside the buildings. This may be because office buildings were mostly located in areas with frequent traffic, and the outdoor $\mathrm{PM}_{2.5}$ concentration was high, which was conducive to the spread of bacteria. The richness and uniformity of bacteria outside the office building were higher than other types of buildings.

In summary, when the building types were the same, the bacterial diversity was higher in rural areas with a high concentration of fine particles than that in urban areas. Compared with urban office buildings and residential buildings, indoor bacterial diversity was similar to residential buildings, and the outdoor bacterial diversity of office buildings was significantly higher than that of urban residential buildings. This may be associated with the fact that office buildings were mostly located in areas with frequent traffic and outdoor PM2.5 pollution was serious.

\section{Conclusion}

This study investigated the indoor and outdoor fine PM, and its bacterial contamination in Daqing, a severe cold region in China. The main conclusions were as follows:

(1) Regarding indoor and outdoor $\mathrm{PM}_{2.5}$ pollution in the heating season, the average indoor and outdoor $\mathrm{PM}_{2.5}$ concentrations in office buildings were higher than in residential buildings, which was higher than teaching buildings.

(2) The overall exposure of adults was higher than that of children. The average comprehensive exposure of males and females was not different. The risk of fine particle exposure in urban areas was higher than that in rural areas, and the risk of $\mathrm{PM}_{2.5}$ exposure in males was higher than that in females.

(3) The main bacteria of three types buildings in Daqing were Proteobacteria, Bacteroidetes, and Firmicutes. The bacterial diversity was higher in rural residential buildings with a high fine particle concentration than that in urban. The bacterial diversity of outdoor office buildings was significantly higher than that of outdoor residential buildings.

\section{Author Contributions}

Conceptualization and methology was proposed by YL; formal analysis and data curation was conducted by HW and $\mathrm{XC}$; writing - original draft preparation, review and edit and project administration were done by $\mathrm{YL}$

\section{References}

Braithwaite I, S Zhang, JB Kirkbride, PJO David, FH Joseph (2019). Air pollution (particulate matter) exposure and associations with depression, anxiety, bipolar, psychosis and suicide risk: A systematic review and meta-analysis. Environ Health Persp $127: 126002$

Cao D, W Gao, J Wu, K Lv, S Xin, Y Wang, G Jiang (2018). Occurrence and human exposure assessment of short- and medium-chain chlorinated paraffins in dusts from plastic sports courts and synthetic turf in Beijing, China. Environ Sci Technol 53:443-451

Chen H, X Li, M Yao (2020). Rats sniff off toxic air. Environ Sci Technol 54:3437-3446

Chen R, P Yin, X Meng, C Liu, L Wang, X Xu, A Ross Jennifer, A Tse Lap, Z Zhao, H Kan, M Zhou (2017). Fine particulate air pollution and daily mortality. a nationwide analysis in 272 Chinese cities. Amer J Resp Crit Care Med 196:73-81 


\section{Bacterial Diversity in Severe Cold Region of China / Intl J Agric Biol, Vol 25, No 2, 2021}

Després RV, JA Huffman, SM Burrows, C Hoose, A Safatov, G Buryak, J Fröhlich-Nowoisky, W Elbert, M Andreae, U Pöschl, R Jaenicke (2012). Primary biological aerosol particles in the atmosphere: A review. Tellus B Chem Phys Meterol 64:1-59

Dons E, LI Panis, MV Poppel, J Theunis, H Willems, R Torfs, G Wets (2011). Impact of time-activity patterns on personal exposure to black carbon. Atmos Environ 45:3594-3602

Edgar RC (2013). UPARSE: Highly accurate OTU sequences from microbial amplicon reads. Nat Meth10:996-998

Ernest H (2004). A Textbook of Modern Toxicology, $3^{\text {rd }}$ Edition. A John Wiley \& Sons, Inc., Publication, U.S.A.

Estillore AD, JV Trueblood, VH Grassian (2016). Atmospheric chemistry of bioaerosols: Heterogeneous and multiphase reactions with atmospheric oxidants and other trace gases. Chem Sci 7:6604-6616

Frhlich-nowoisky J, CJ Kampf, B Weber, JA Huffman, C Pöhlke, O Meinrat (2016). Bioaerosols in the earth system: Climate, health, and ecosystem interactions. Atmos Res 182:346-376

Gao ZY (2010). Study on the health effects and genetic susceptibility of atmospheric fine particle population exposure. Fudan University, Shanghai, China

GBT18883-2002 (2002). Indoor air quality standards. Beijing: State Environmental Protection Administration. (In Chinese)

GB3059-2012 (2012). Ambient air quality standards. Beijing: State Environmental Protection Administration. (In Chinese)

Graham B, P Guyon, W Maenhaut, PE Taylor, M Ebert, S Matthias-Maser, OL Mayol-Bracero, RHM Godoi, P Artaxo, FX Meixner, MA Moura, CH EçaD'AlmeidaRocha, RV Grieken, MM Glovsky, RC Flagan, MO Andreae (2003). Composition and diurnal variability of the natural Amazonian aerosol. J Geophys Res Atmos 108:1-17. 10.1029/2003JD003990

Haberzettl P, O'Toole, E Timothy, A Bhatnagar, D Conklin (2016). Exposure to fine particulate air pollution causes vascular insulin resistance by inducing pulmonary oxidative stress. Environ Health Persp 124:1830-1839

He C, L Morawska, J Hitchins, D Gilbert (2004). Contribution from indoor sources to particle number and mass concentrations in residential houses. Atmos Environ 38:3405-3415

Huffman A, AJ Prenni, PJ DeMott, C Pöhlker, RH Mason, NH Robinson, J Fröhlich-Nowoisky, Y Tobo, VR Després, E Garcia, DJ Gochis, E Harris, I Müller-Germann, C Ruzene, B Schmer, B Sinha, DA Day, MO Andreae, JL Jimenez, M Gallagher, SM Kreidenweis, AK Bertram, U Pöschl (2013). High concentrations of biological aerosol particles and ice nuclei during and after rain. Atmos Chem Phys 13:6151-6164

Huffman JA, B Sinha, RM Garland, A Snee-Pollmann, SS Gunthe, P Artaxo, ST Martin, MO Andreae, U Pöschl (2012). Size distributions and temporal variations of biological aerosol particles in the Amazon rainforest characterized by microscopy and real-time UV-APS fluorescence techniques during AMAZE-08. Atmos Chem Phys 12:11997-12019

JGJ/T309-2013 (2013). Building ventilation effect test and evaluation standards. Beijing: Ministry of Housing and Urban-Rural Development of the People's Republic of China. (In Chinese)

Ji W, B Zhao (2015). Contribution of outdoor-originating particles, indooremitted particles and indoor secondary organic aerosol (SOA) to residential indoor $\mathrm{PM}_{2.5}$ concentration: A model-based estimation. Build Environ 90:196-205

Li J, H Chen, X Li, X Wang, X Zhang, J Cao, F Shen, Y Wu, S Xu, H Fan, G Da, R Huang, J Wang, CK Chan, AL Jesus, L Morawska, M Yao (2019a). Differing toxicity of ambient particulate matter (PM) in global cities. Atmos Environ 212:305-315

Li Y, Y Ji, J Zhang, J Zhao, S Wang, L Zhang (2019b). Characteristics and source analysis of $\mathrm{pm}_{25}$ element pollution in the atmosphere in Panjin City in Winter. Environ Chem 38:1891-1898

Li J, J Cao, Y Zhu, Q Chen, F Shen, Y Wu, S Xu, H Fan, G Da, R Huang, J Wang, L de Jesus Alma, M Lidia, K Chan Chak, P Jordan, M Yao (2018). Global survey of antibiotic resistance genes in air. Environ Sci Technol 52:10975-10984

Li J, M Li, F Shen, Z Zou, M Yao, C Wu (2013). Characterization of biological aerosol exposure risks from automobile air conditioning system. Environ Sci Technol 47:10660-10666
Liu X, Q Zheng, G Hu, R Yu (2019a). Distribution characteristics and health risk assessment of heavy metals in PM_ (2.5) from road dust in Nanchang City. Environ Chem 38:1609-1618

Liu XJ, W Zhang (2012). Medical Microbiology. China Medical Science and Technology Press, China

Liu Z, H Yin, S Ma, B Wei, B Jensen, G Cao (2019b). Effect of environmental parameters on culturability and viability of dust accumulated fungi in different HVAC segments. Sustain Cities Soc 48:101538

Ministry of Environmental Protection (2013a). Handbook of Exposure Parameters for Chinese Population (Adult). China Environment Press, Beijing, China

Ministry of Environmental Protection (2013b). Handbook of Exposure Parameters for Chinese Population (Children). China Environment Press,0 Beijing, China

Monn C (2001). Exposure assessment of air pollutants: A review on spatial heterogeneity and indoor/outdoor/personal exposure to suspended particulate matter, nitrogen dioxide and ozone. Atmos Environ $35: 1-32$

Qi Y, LH Chen, L Zhang, YY Yang, SY Zhan, CX Fu (2020). Public cognition, attitude and behavior of novel coronavirus pneumonia. $J$ Tropical Med 20:145-149

Quast C, E Pruesse, P Yilmaz, G Jan, S Timmy, Y Pablo, P Jörg, GF Oliver (2013). The SILVA ribosomal RNA gene database project: Improved data processing and web-based tools. Nucl Acids Res 41:D590-D596

Wang B, Z Wang, X Zhao, N Huang, X Duan, Y Jiang, L Wang (2014). Research on indoor and outdoor activities of adults in China. $J$ Environ Health 31:945-948

Wang J, Y Zheng, Z Liu, M Yao, X Li, J Zhuang, W Peng (2018). The similarities and differences between exhaled VOCs in patients with upper respiratory infections and healthy people. J Peking Univ Nat Sci 54:807-814

Wang JN, TT Li, YB Lv, B Kraus Virginia, Y Zhang, C Mao, ZX Yin, WY Shi, JB Zhou, TZ Zheng, PL Kinney, J Ji, S Tang, XM Shi (2020). Fine particulate matter and poor cognitive function among Chinese older adults: Evidence from a community-based, 12-year prospective cohort study. Environ Health Persp 128; Article 67013

Wang Q, MG George, MT James, RC James (2007). Naive Bayesian classifier for rapid assignment of rRNA sequences into the new bacterial taxonomy. Appl Environ Microbiol 73:5261-5267

Wang W, H Fu, T Wang, Y Song, J Fu, M Xiang, Y Li (2015). Characteristics of bacterial and fungal aerosols during the autumn haze days in Xi'an, China. Atmos Environ 122:439-447

Wei F, E Teng, G Wu, W Hu, WE Wilson, RS Chapman, JC Pau, J Zhang (2001). $\mathrm{PM}_{2.5}$ and $\mathrm{PM}_{10}$ pollution and their chemical composition in the air of four large cities in China. Chin Environ Monit 2001; Article 4

Wei HJ, YP Zhang (2018). Liaoning Statistical Yearbook. China Statistical Publishing House: Beijing, China

Yan B, S Liu, B Zhao, X Li, Q Fu, G Jiang (2018). China's fight for clean air and human health. Environ Sci Technol 52:8063-8064

Yin P, M Brauer, A Cohen, RT Burnett, J Liu, Y Liu, R Liang, W Wang, J Qi, L Wang, M Zhou (2017a). Long-term fine particulate matter exposure and nonaccidental and cause-specific mortality in a large national cohort of Chinese Men. Environ Health Persp 125: 1-11

Yin P, G He, M Fan, KY Chiu, M Fan, C Liu, A Xue, T Liu, L Tong, Y Pan, Q Mu, M Zhou (2017b). Particulate air pollution and mortality in 38 of China's largest cities: Time series analysis. BMJ 356:1-12

Yip FY, GJ Keeler, JT Dvonch, TG Robin, EA Parker, BA Israel, W Brakefield-Caldwell (2004). Personal exposures to particulate matter among children with asthma in Detroit, Michigan. Atmos Environ 38:5227-5236

Yu S, Z Yu, P Liu, G Feng (2019). Influence of environmental factors on wall mold in underground buildings in Shenyang City, China. Sustain Cities Soc 46:101452

Zhang XP, MH Lin (2019). Inspection of air pollution types and EKC morphology in China's key environmental protection cities. In: Abstracts of the Annual Meeting of The Economic Geography Committee of the Chinese Geographical Society in 2019 Economic Geography Professional Committee of Chinese, China 